PRETHODNO PRIOPĆENJE

UDK: 005.94(497.115)

\author{
PhD can. Albana Berisha Qehaja \\ PhD. Enver Kutllovci \\ PhD. Ymer Havolli
}

\title{
LEARNING ORGANIZATION SURVEY: A STUDY IN KOSOVAN ENTERPRISES
}

\author{
ISTRAŽIVANJE UČEĆE ORGANIZACIJE: \\ PRIMJER KOSOVSKIH TVRTKI
}

\begin{abstract}
The main purpose of this research is assessing the fundamental learning elements, considered as prerequisites for an enterprise to become a learning organization. More specifically, the research on the supportive learning environment, concrete learning processes and practices, and leadership that reinforces learning in Kosovan enterprises. This paper discusses how important and crucial is for enterprises to become learning organizations. A quantitative survey was conducted among 150 selected Kosovan enterprises. Learning Organization Survey - LOS is utilized as an assessment tool. This tool was chosen to assess the degree to which the Kosovan enterprises function as Learning Organization. The research results have highlighted that Kosovan enterprises have fallen short in implementing the Learning Organization since the scores were below the benchmark set up by Garvin et al. (2008). This study is likely to contribute to decision makers and leaders keen to improve the learning environment, learning processes and practices and to reinforce learning within their enterprises. Also, it pinpoints the areas needing improvement in the Kosovan enterprises in this context.
\end{abstract}

KEY WORDS: Learning environment, Learning process, Learning organization, Learning Organization Survey - LOS, Kosovo.

SAŽETAK: Osnovni cilj ovoga istraživanja je procijeniti osnovne elemente učenja koji se smatraju preduvjetima da bi poduzeće postalo 'učeća organizacija'. Zapravo se radi o istraživanju okoline koja podupire učenje, konkretnih procesa i praksi učenja te rukovoditelja koji potiču učenje u kosovskim tvrtkama. Ovaj rad razmatra koliko je važno i ključno za tvrtke da postanu učeće organizacije. Kvantitativno istraživanje provedeno je u 150 odabranih kosovskih tvrtki, a kako bi se odredio stupanj u kojemu su kosovske tvrtke učeće organizacije korišten je alat za procjenu učenja LOS. Rezultati istraživanja otkrivaju da kosovske tvrtke nedovoljno primjenjuju postulate učeće organizacije budući da nisu dostigli mjerilo koje je postavio Garvin et al. (2008.). Ova studija može pomoći donositeljima odluka i liderima koji žele poboljšati okruženje za učenje te učeće procese i prakse kako 
bi osnažili učenje u svojim tvrtkama. Ona, također, locira područja kosovskih tvrtki koja zahtijevaju poboljšanja u ovome smislu.

KLJUČNE RIJEČI: okruženje za učenje, učeći proces, učeća organizacija, Ispitivanje učeće organizacije (IUO), Kosovo.

\section{INTRODUCTION}

To successfully compete in today's world, firms must increasingly rely on the knowledge, skills, and experience of their human assets to create and assimilate new knowledge, innovate, and learn to compete in fast-moving business environments (Jackson et al., 2003). The new organization that emerges will need to possess greater knowledge, flexibility, speed, power, and learning ability so as to better confront the shifting needs of a new environment, more demanding customers, and smarter knowledge workers (Marquard, 2002). Additionally, Marquard (2002) has highlighted eight crucial forces in the XXI century, which would transform the world of business towards greater need for constant learning, and among them is the emergence of knowledge and learning as major organizational assets.

Knowledge is one of the most important organizational resources in regard to performance (Ma \& Yu, 2010; Wang \& Noe, 2010) and the culture oriented toward supporting learning can lead to improved performance (Marsick \& Watkins, 2003). Shipton et al. (2013) on a sample comprising nearly 6000 organizations across 15 countries, found that Learning Organizations (hereinafter often referred to as LO) exhibit higher performance than their less learning-inclined counterparts. Hence, if we manage to integrate knowledge in the learning and organizational culture, it will doubtless increase the success of the companies. Effectively managing human resources for knowledge-based competition requires adopting a strategic approach.

This topic has been and remains a subject of discussion among academics, researchers and experts in strategic management field. According to Birdthistle (2008), many theorists and practitioners view the transition to a $\mathrm{LO}$ as crucial to enable companies to unlock the learning potential of individuals and groups to gain and sustain competitive advantage. Whereas, according to the Boston Consulting Group (2010), becoming a LO provides a clear competitive advantage and will become more important in the future. However, there are still discussions on the importance of $\mathrm{LO}$ which will be raised in the literature review.

The key goal of this study is assessing the fundamental learning elements, considered as prerequisites for an enterprise to become a learning organization. Consequently, there are certain questions to be probed and answered. What is the typical learning process in the Kosovan enterprises? How does it compare with others? To answer these questions, we surveyed managers from 150 enterprises, using the assessment tool "Learning Organization Survey" (hereinafter often referred to as LOS), developed by Garvin et al. (2008).

There are few studies that have raised this issue in the south-eastern Europe countries. We have not encountered another study of the analysis of the Kosovan enterprises in terms of LO. Accordingly, we think this is the first study that investigates the Kosovan enterprises in the learning organization context and compares the results with similar studies in the region. 
This study is likely to contribute to decision makers and leaders in Kosovan enterprises, keen to improve the learning environment, processes, and practices. Also, this model could serve as a representative sample for further research in southeastern countries.

\section{LITERATURE REVIEW}

There still exists confusion regarding what is learning and how to distinguish it from unreflective change (Fiol \& Lyles, 1985). According to Farrell (2000), the ability to learn is a priority for organizations that wish to compete effectively. Lee and Choi (2003) defined learning and development as the degree to which learning and development is encouraged in an organization. However, individual learning is as old as humanity itself. Individuals are fundamental to the development of organizational learning (Argyris \& Schön, 1978). Senge (1990, p.124) emphasized: "Organizations learn only through individuals who learn. Individual learning does not guarantee organizational learning. But without it no organizational learning occurs." Argyris and Schön (1978) developed for the first time the theory of organizational learning in the late of $70 \mathrm{~s}$ and the topic switched to treatment at the level of organization and learning process within the organization.

According to Birdthistle (2008), by far the most significant and influential piece of writing from within the learning organization literature is Senge (1990). He adopted a broader approach by merging perspectives and by promoting five key disciplines of the LO, which include: (i) personal mastery, (ii) mental models, (iii) shared vision, (iv) team learning and (v) system thinking. In the following, it is presented a summary of these five key disciplines.

Lifelong learning, an important form of individual learning, is a part of commitment to personal mastery (Appelbaum \& Goransson, 1997; Senge, 2006). Personal mastery refers to a particular level of ability, like a master dedicated to all life and constantly improves and perfects its skills. Senge (1990, p.10) sees personal mastery as "an essential cornerstone of the learning organization-the learning organization's spiritual foundation." Assumptions held by individuals and organizations are called mental models and are known as the individual commitment to the learning process. As believed by Gephart et al. (1996), by sharing best practices, mental models strengthen people's commitment to learning. If mental models are developed and learned throughout the organization, one of the results is a higher level of knowledge sharing and knowledge creation (Watkins \& Marsick, 1993; Senge, 2006). Shared vision means vision owned by all levels. It creates focus and energy for learning (Senge, 1990). Building shared vision is important for bringing people together and to foster a commitment to a shared future (Appelbaum \& Goransson, 1997). As stated by Senge (1990), systems thinking is a conceptual framework, a body of knowledge and tools that have been developed over the past fifty years, to make the full patterns clearer, and to help us see how to change them effectively. Working teams are an important part of the organization. They should be able to think, create and learn effectively as one entity. In the opinion of O'Keeffe (2002), the accumulation of individual learning constitutes team learning. A successful team learning system ensures that teams share their experiences, both negative and positive, with other groups in the organization and thereby promote vigorous corporate intellectual growth (Marquardt, 2002). According to Senge (2006), all the 
members learn together and manifest a level of collective intelligence greater than the sum of the intelligence of the individual members. Similarly to Senge, Marquardt (2002) includes Learning subsystems (see figure 1).

Although trained by very different academic disciplines, Senge and Argyris both advocate a cognitive approach to intervening in organizations to improve their adaptability and effectiveness (Edmondson \& Moingeon, 1998). Bui and Baruch (2010) empathized that Senge's "fifth discipline" philosophy is inspirational, yet difficult to translate into a model that would enable systematic evaluation of the process of creating LO. Marquardt (2002) based on his experience in 100 of the top LOs worldwide emphasized that before individuals or companies can adequately comprehend the richness of the LO they must incorporate five subsystems: learning, organization, people, knowledge, and technology. Without all five subsystems, they will have only a partial appreciation of the processes and principles necessary to move an organization from a state of nonlearning to learning" (see figure 2).

The Learning Subsystems and Systems Learning Model are presented in figure 1 and 2 .

Figure 1. Learning Subsystem

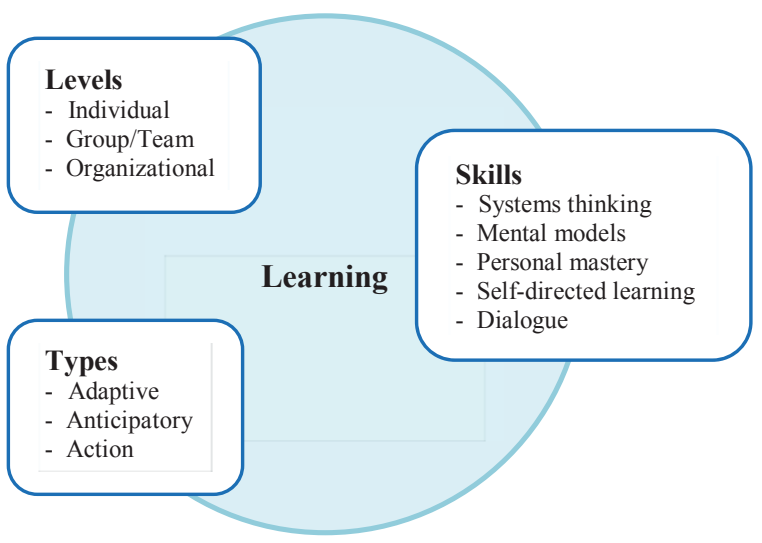

Figure 2. Systems Learning Organization Model

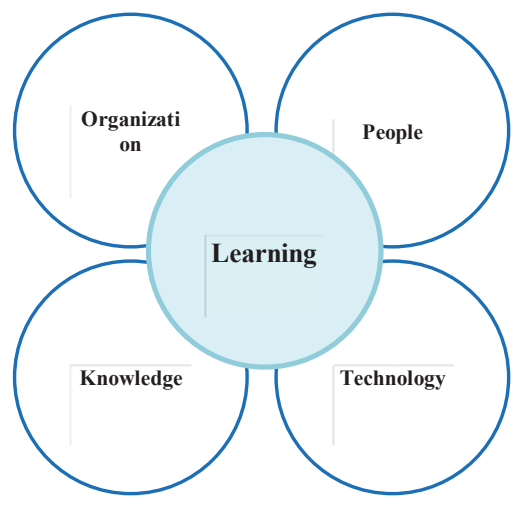

Source: Marquardt, M. J. (2002), Building the learning organization: Mastering the 5 elements for corporate learning, Davies-Black Pub.Inc., pp. 24-25.

The concept of LO has been the focus of management theorists and practitioners because of his theoretical development, but also for its practical implications (Mintzberg et al., 1998). During the 1990s, the number of firms committing themselves to becoming LOs increased dramatically. Companies such as General Electric, Johnsonville Foods, Quad Graphics, and Pacific Bell in the United States; Sheerness Steel, Nokia, Sun Alliance, and ABB in Europe; and Honda and Samsung in Asia were among the early pioneers (Marquard, 2002).

Some definitions of the LOs are presented in following. Senge (1990) defines LO as a place where people continually expand their capacity to create the results they truly desire, where new and expensive patterns of thinking are nurtured, where collective aspiration is set free, and where people are continually learning how to learn together. According to Watkins and Marsick (1992), LOs are characterized by total employee involvement in 
a process of collaboratively conducted, collectively accountable change directed towards shared values or principles. For Garvin et al. (2008) LOs are places where employees excel at creating, acquiring and transferring knowledge. Whereas, according to Bui and Baruch (2010), LOs are organic 'systems' of shared learning rather than impersonal bureaucratic machines or market-driven entities focused on individual self-interest and competition.

O'Keeffe (2002) considered that the characteristics of a LO are factors that are gradually acquired, rather than developed simultaneously. In the following, we will present a summary of LO characteristics as stated by selected authors, which were given by Kontoghiorghes et al. (2005): Open communications (Appelbaum \& Reichart, 1998; Gardiner \& Whiting, 1997; Phillips, 2003; Pool, 2000). Risk taking (Appelbaum \& Reichart, 1998; Goh, 1998; Richardson, 1995; Rowden, 2001). Support and recognition for learning (Bennett \& O’Brien, 1994; Griego et al., 2000; Wilkinson \& Kleiner, 1993). Resources to perform the job (Pedler et al., 1991). Teams (Appelbaum \& Goransson, 1997; Anderson, 1997; Goh, 1998; Salner, 1999; Strachan, 1996; Senge, 1990); Rewards for learning (Griego et al., 2000; Lippitt, 1997; Phillips, 2003). Training and learning environment (Gephart et al. 1996; Goh, 1998; Robinson et al., 1997); Knowledge management (Loermans, 2002; Selen, 2000).

There have been many criticisms toward LO. Salaman and Butler (1994) stated that not only may employees resist organizational learning, the LO concept ignores the way that power is exercised, and the behaviours that are rewarded and penalized. Whilst, Rebelo and Gomes (2008) emphasized that the interests in this concept started to wane slightly and the suspicion that it was merely a fashion has increased, as have the critical voices around it. Unfortunately, this concept (the LO) is like a cubist painting - full of ambiguous viewpoints (Smith \& Saint-Onge, 1996). As noted by Garvin et al. (2008), the ideal of the LO has not yet been realized. A recent review by Santa (2015) revealed that the LO violates the properties of the "good" theory, especially the definitions' and relationships' properties. Grieves (2008) made a call we should abandon the idea of the LO. Lately, Rowley and Gibbs (2008, p.368) suggested a new version of the model of the LO, the practically wise organization, one which "captures knowledge and learning created by a deliberate engagement with its environment and becomes skillful at the engagement through experience, practice and judgment."

To identify and support successful change in a dynamic competitive environment, some researches (Garvin et al., 2008; Bui \& Baruch, 2010) agree on creating a tool to measure organizations in the context of learning. Several questionnaires have been developed to test/assess the enterprises if they are LOs or not (Watkins \& Marsick, 1993; Goh \& Richards, 1997; Pedler et al., 1997; Garvin et al., 2008). Garvin et al. (2008) developed a diagnostic survey "The Learning Organization Survey" to determine how well the company functions as a LO and to identify areas for improvement. This tool can be used at any level of organization, and it is based on three building blocks that are crucial to becoming an LO: supportive learning environment, concrete learning processes and practices, and leadership that reinforces learning.

Garvin et al. (2008) emphasized that this diagnostic survey is designed to help you determine how well your company functions as a learning organization. In addition, they highlighted: "By assessing how well your team, unit, or company exhibits the defining characteristics for each building block, you identify areas for improvement" (p. 1). 


\section{KOSOVAN ENTERPRISES CONTEXT}

Kosova is still in the transition phase in which entrepreneurship and small business creation is expected to play an important role on the road to a modern economy, free market and thus towards development and economic growth (MTI, 2015). Small and medium enterprises (hereinafter often referred to as SME) can play an increasingly essential role in this delayed transition trajectory, especially if we consider that the private sector in Kosova consists almost entirely of SMEs (Krasniqi, 2007). However, SMEs in Kosova continue to face institutional barriers and other obstacles created by the business environment, including lack of quality education, poor knowledge and lack of experience in the use of new technologies (Peci et al., 2012).

As it's seen in the table 1, out of $100 \%$ of Kosovan enterprises, $99 \%$ of them are SMEs.

Table 1: Registered Enterprises in Kosovo based on Number of Employees - 2010

\begin{tabular}{|l|r|c|c|}
\hline $\begin{array}{c}\text { Classification by } \\
\text { Size }\end{array}$ & $\begin{array}{c}\text { Number of } \\
\text { Employees }\end{array}$ & $\begin{array}{c}\text { Number of } \\
\text { Enterprises }\end{array}$ & Percentage of Total \\
\hline Micro & $1-9$ & 102.070 & 98.37 \\
\hline Small & $10-49$ & 1.406 & 1.35 \\
\hline Medium & $50-249$ & 221 & 0.22 \\
\hline Large & 250 or more & 58 & 0.06 \\
\hline Total & & $\mathbf{1 0 3 . 7 5 5}$ & $\mathbf{1 0 0 . 0 0}$ \\
\hline
\end{tabular}

Source: MTI (2011). SME Development Strategy for Kosovo 2012-2016, pp. 13.

Kosovo has a new labour force and growing, which needs to be educated and trained in order to meet the needs of the economy. More than $50 \%$ of Kosovo's population is under the age of 25 and $70 \%$ of them under the age of 35 (MTI, 2011). These statistical facts are promising with regard to the potential of Kosovans to develop new learning processes and practices in Kosovan enterprises. Although, the results of a report in Kosovo, state that the majority of SMEs' owners (75.6\%) are also managers. These findings indicate that SMEs in Kosovo may have problems of managerial capacities in solving managerial problems and this of course may inhibit firms from achieving their full potential (BSC Kosovo, 2011). The results of a recent study of human resource perceptions in distribution firms in Kosovo, revealed that the current perception of HR may bring just Competitive Parity not the Competitive Advantage in the terms of human resources (Berisha Qehaja \& Kutllovci, 2015).

\section{RESEARCH METHODOLOGY}

Since there is no firm consensus on one best measurement tool for LO (Jamali \& Sidani, 2008), the survey used in this study was based on the "LOS" (Garvin et al., 2008) to determine how well the Kosovan enterprises function as LOs and pinpointing the areas needing improvement. This survey was chosen for two reasons: first, it was used in some recent studies (Finnigan \& Daly, 2012; Horvat \& Trojak, 2013; Renner et al., 2013; Porter, 
2016), and second, it was easy to administer it since it was designed to explore indirectly the basic elements of LO.

The study is based on primary data gathered in Kosovo enterprises within three months (January-March, 2014) through a survey in the following sectors: production, trade, and service. The nature of this research is empirical. Sampling was pre-selected through non-probability method, extracted from the last database of the Tax Administration of Kosovo (TAK).

Survey respondents were managers from different departments. According to Nonaka and Takeuchi (1995), middle managers are the true "knowledge engineers" of the knowledge-creating company. Thus, we decided to survey managers of the various departments to elicit more accurate results.

The total sample size was 150 enterprises. Out of $100 \%$ of them, $40 \%(n=60)$ were trade enterprises; $30 \%(n=45)$ were production enterprises, and $30 \%(n=45)$ were service enterprises. Regarding the size of enterprises, $50 \%$ of them fall into category of small sized firms, $19.34 \%$ belong to medium sized enterprises and $30.66 \%$ belong to large sized enterprises.

The questionnaire consisted of two parts. The first part included general questions about respondents and enterprises; the second part included questions from "LOS".

There were several questions about three building blocks subcomponents as mentioned in the earlier part. All of them were measured on a seven-point Likert scale for the first and second blocks, whereas a five-point scale for the third block. The average time to complete the questionnaire was 20 minutes.

During the data analysis, we compared each sectors' scores with the benchmarks ${ }^{1}$, in a way to identify areas of excellence and opportunities for improvement. The research results are compared with those from Croatian enterprises, conducted by Horvat and Trojak (2013), who used the same assessment tool.

\section{RESEARCH RESULTS}

Of the total respondents, 114 were males (76\%) and 36 females (24\%). It is evident that men are engaged in managerial levels of Kosovan enterprises much more than women. Their average age was 35 years. Their professional preparation was as follows: $0.74 \%$ were with primary education only, $8.88 \%$ with secondary education, $56.30 \%$ with high education and $34.08 \%$ with a superior education. These results are due to the fact that our respondents were middle managers. Otherwise, according to BSC Kosovo (2013), around 69\% of SME employees are more likely to be qualified with a gymnasium and other professional secondary school education level.

\footnotetext{
${ }^{1}$ The authors of this tool provided benchmark data, derived from surveys of large groups of senior executives in a variety of industries who completed an eight week general management program at Harvard Business School. They first conducted the survey in the spring of 2006 with 100 executives in order to evaluate the statistical properties of the survey and assess the underlying constructs. That autumn they surveyed another 125 senior executives to use as their benchmark data.
} 


\section{Research results and benchmarking}

Our attempt was to investigate the level of the supportive learning environment in the workplace. This issue was explored based on the assumption that enterprises with the bureaucratic management system have little space for creative ideas and proposals on new ways and approaches to problem solutions. According to Hamel (2006), if you want to build an organization that unshackles the human spirit, you're going to need some decidedly unbureaucratic management principles. Marquardt (2002) pointed out that fewer boundaries and bureaucracies allow the lifeblood of knowledge to flow quickly and freely throughout the organization. Earlier, Peters (1987) stressed out that "demolishing" their own bureaucracies is an absolute priority for all LOs.

Garvin et al. (2008) presented that environment that supports learning bears these four key distinguishing characteristics: psychological safety, appreciation of differences, openness to new ideas and time for reflection. In the questionnaire there were many questions probing specifically learning processes and practices. Finally, we investigated the level of leadership that reinforce learning in those enterprises. In this section, detailed results of this empirical study are presented.

The research results for three sectors of Kosovan enterprises are summarized in the following Table 2 and Chart 1.

Table 2: Benchmarking of results

\begin{tabular}{|c|c|c|c|c|c|c|c|c|c|}
\hline \multicolumn{5}{|c|}{ Scaled Scores - Kosovan Enterprises } & \multicolumn{5}{|c|}{ Scaled Scores (Garvin et al., 2008) } \\
\hline $\begin{array}{l}\text { Building Blocks and Their } \\
\text { Subcomponents }\end{array}$ & 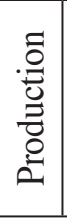 & 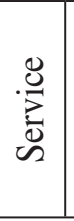 & 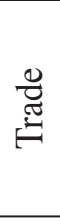 & 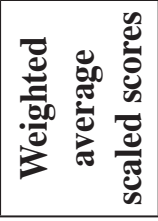 & 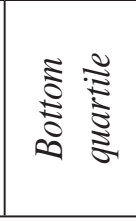 & 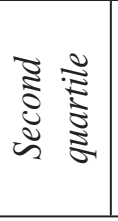 & 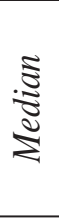 & 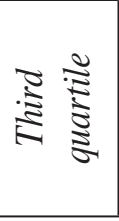 & 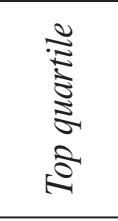 \\
\hline \multicolumn{10}{|c|}{ Supportive Learning Environment } \\
\hline Psychological safety & 80 & 69 & 80 & 76.7 & $31-66$ & $67-75$ & 76 & $77-86$ & $87-100$ \\
\hline Appreciation 0 & 61 & 64 & 68 & 64.7 & $14-56$ & $57-63$ & 64 & $65-79$ & $80-100$ \\
\hline Openness t & 61 & 64 & 61 & & $38-80$ & $81-89$ & 90 & $91-95$ & \\
\hline Time for reflection & 51 & 48 & 43 & 46.9 & $14-35$ & $36-49$ & 50 & $51-64$ & $65-100$ \\
\hline $\begin{array}{l}\text { Learning environment } \\
\text { composite }\end{array}$ & 63 & 61 & 63 & 62.4 & $31-61$ & $62-70$ & 71 & $72-79$ & $80-90$ \\
\hline \multicolumn{10}{|c|}{ Concrete Learning Processes and Practices } \\
\hline Experimentation & 82 & 86 & 64 & 76.0 & $18-53$ & $54-70$ & 71 & $72-82$ & $83-100$ \\
\hline Information & 76 & 81 & 88 & 82.3 & $23-70$ & $71-79$ & 80 & $81-89$ & $90-100$ \\
\hline Analysis & 66 & 71 & 63 & 66.3 & $19-56$ & $57-70$ & 71 & $72-86$ & $87-100$ \\
\hline Education an & 74 & 88 & 74 & 78.2 & $26-68$ & $69-79$ & 80 & $81-89$ & $90-100$ \\
\hline Information transfer & 64 & 75 & 75 & 71.7 & $34-60$ & $61-70$ & 71 & $72-84$ & $85-100$ \\
\hline Learning processes composite & 51 & 49 & 50 & 50.0 & $31-62$ & $63-73$ & 74 & $75-82$ & $83-97$ \\
\hline \multicolumn{10}{|c|}{ Leadership That Reinforces Learning } \\
\hline Composite for this block & 63 & 73 & 58 & 64.0 & $33-66$ & 67-75 & 76 & $77-82$ & $83-100$ \\
\hline
\end{tabular}


Chart 1: Benchmarking of results

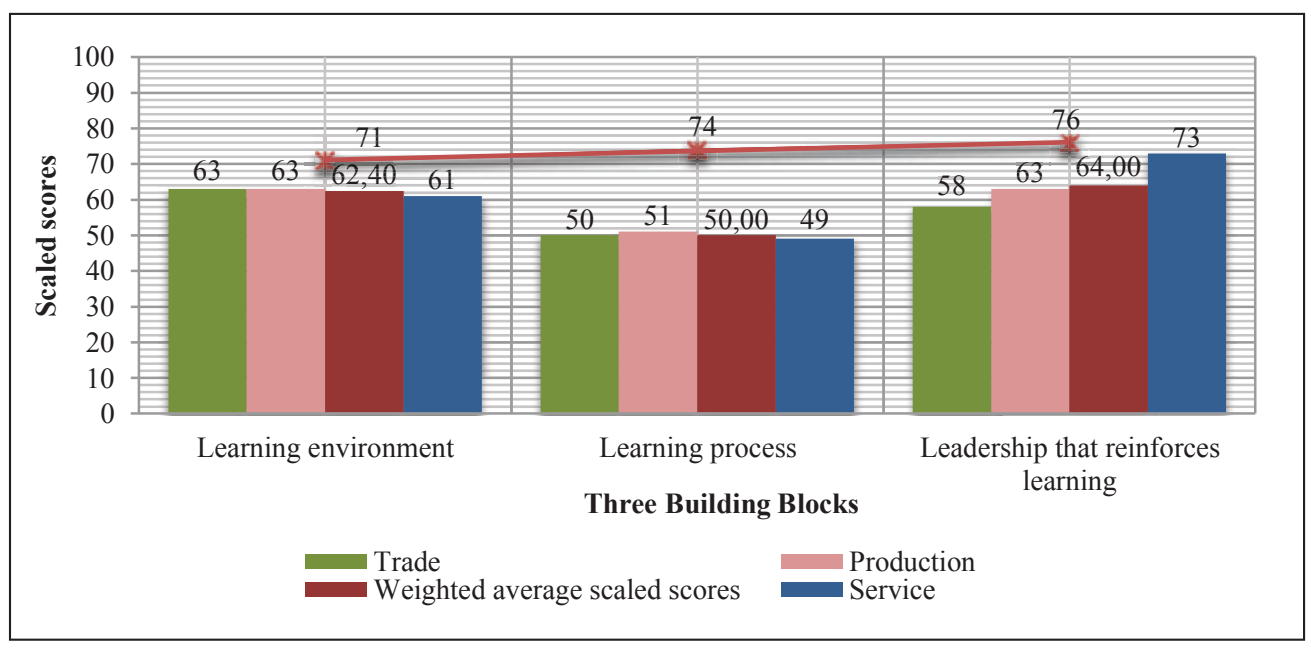

Results in Table 2 show that two subcomponents (psychological safety and appreciation of differences) fall into the category of third quartile. Whereas, the third one (openness to new ideas) has the weakest result from the first block subcomponents and fall into the category of bottom quartile and the fourth one (time for reflection) fall into the category of second quartile. Moreover, we found few differences in the scores for three sectors of the learning environment. Hence, it can be said Kosovan enterprises with a weighted average composite score of 62.4 in learning environment, fall into the category of the second quartile.

Furthermore, regarding the learning processes and practices, there is almost no difference between these sectors. So, it can be concluded that the Kosovan enterprises with a weighted average score of 50.0 in learning processes and practices, fall into the category of the bottom quartile.

Unlike the two first blocks, in the leadership that reinforces learning (the third block), there are significant differences between sectors, especially in the service sector. This sector falls under the category of the second quartile, unlike the other two sectors that fall under the category of the bottom quartile. Although, with a weighted average score of 64.0 for leadership that reinforces learning block, the Kosovan enterprises fall into the category of the bottom quartile.

Based on these results, it is indicated that Kosovan enterprises have fallen short in implementing Learning Organization since the scores were below the benchmark set up by Garvin et al. (2008). As recommended by them, these enterprises should consider initiating an improvement effort. One possibility is to assemble a team to brainstorm specific, concrete strategies for enhancing the area of weakness.

\section{DISCUSSION AND CONCLUSIONS}

Kontoghiorghes et al. (2005) emphasized that the development of human resource professionals was asked to take the leadership role in the transformation of organizations in order to encourage and promote learning. 
Marquardt (2002) pointed out that many companies do not fully understand what the LO is. As claimed by German managers, LOs exist in a high level in German companies (Perlitz, 1997; Bullinger et al., 1997). In the opinion of Fischer et al. (2002), they were more a reflection of the image that their managers have about the company than what actually happens. Adamska and Minárová (2014) made research in 547 SME in Slovakia to determine to what extent the principles of a LO are applied. They found that selected enterprises broadly apply specific principles to this concept, even if they are not LOs. Also, Djonlagic et al. (2013) conducted a study in 100 enterprises in Bosnia, about assumptions for the implementation of $\mathrm{LO}$ in building competitive advantage. Their results indicated that Bosnian enterprises have relatively developed characteristics of LOs.

The results of this study are compared with the results of Croatian enterprises (Horvat $\&$ Trojak, 2013). Kosovan enterprises scores are presented in dark red colour, whereas, Croatian enterprises scores in blue. When subcomponents scores and weighted average composite scores fall in the same quartile for both countries, the cell has been highlighted with light blue colour.

Table 3: Kosovan enterprises compared to Croatian enterprises and benchmarking

\begin{tabular}{|c|c|c|c|c|c|c|c|}
\hline \multicolumn{3}{|c|}{$\begin{array}{c}\text { Scaled Scores - Kosovan and Croatian } \\
\text { Enterprises } \\
\end{array}$} & \multicolumn{5}{|c|}{ Scaled Scores (Garvin et al., 2008) } \\
\hline $\begin{array}{l}\text { Building Blocks and Their } \\
\text { Subcomponents }\end{array}$ & 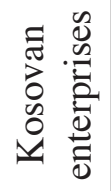 & 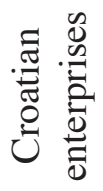 & 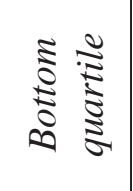 & 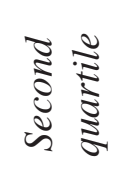 & 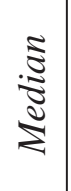 & $\frac{\sqrt{2}}{\sqrt[3]{5}}$ & 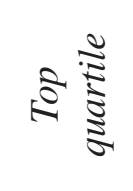 \\
\hline \multicolumn{8}{|l|}{ Supportive Learning Environment } \\
\hline Psychological safety & 76.7 & 73 & $31-66$ & $67-75$ & 76 & $77-86$ & $87-100$ \\
\hline Appreciation of differences & 64.7 & 68 & $14-56$ & $57-63$ & 64 & $65-79$ & $80-100$ \\
\hline Openness to new ideas & 61.9 & 72 & $38-80$ & $81-89$ & 90 & $91-95$ & $96-100$ \\
\hline Time for reflection & 46.9 & 55 & $14-35$ & $36-49$ & 50 & $51-64$ & $65-100$ \\
\hline Learning environment composite & 62.4 & 67 & $31-61$ & $62-70$ & 71 & $72-79$ & $80-90$ \\
\hline \multicolumn{8}{|c|}{ Concrete Learning Processes and Practices } \\
\hline Experimentation & 76.0 & 51 & $18-53$ & $54-70$ & 71 & $72-82$ & $83-100$ \\
\hline Informat & 82.3 & 74 & $23-70$ & $71-79$ & 80 & $81-89$ & $90-100$ \\
\hline Analysis & 66.3 & 61 & $19-56$ & $57-70$ & 71 & $72-86$ & $87-100$ \\
\hline Education and training & 78.2 & 63 & $26-68$ & $69-79$ & 80 & $81-89$ & $90-100$ \\
\hline Information transfer & 71.7 & 55 & $34-60$ & $61-70$ & 71 & $72-84$ & $85-100$ \\
\hline Learning processes composite & 50.0 & 61 & $31-62$ & $63-73$ & 74 & $75-82$ & $83-97$ \\
\hline \multicolumn{8}{|l|}{ Leadership That Reinforces Learning } \\
\hline Composite for this block & 64.0 & 68 & $33-66$ & $67-75$ & 76 & $77-82$ & $83-100$ \\
\hline
\end{tabular}


Chart 2: Kosovan enterprises compared to Croatian enterprises and benchmarking.

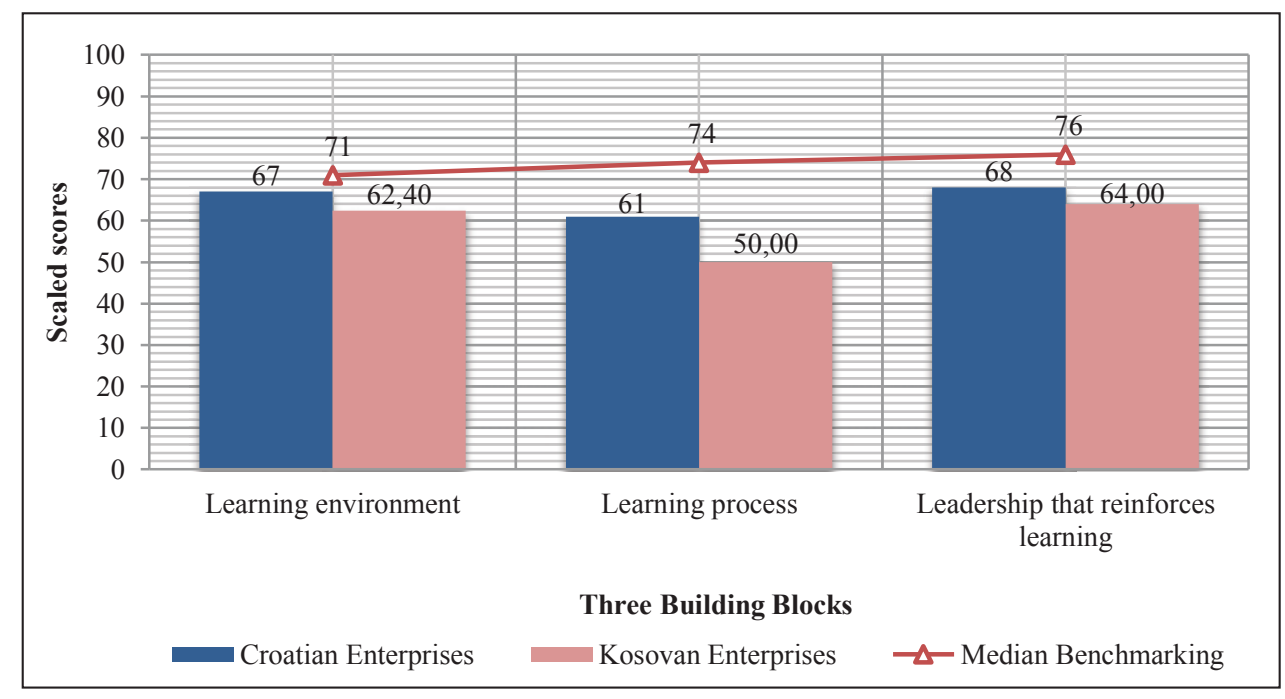

Results in Table 3 and Chart 2 show there are few differences in Kosovan and Croatian enterprises regarding the learning environment. Itcanbe saidenterprises of bothcountriesfallinto the category of the second quartile. Whereas, regarding the learning processes and practices, it is indicated that Croatian enterprises are in advantage compared to the Kosovan enterprises. Nevertheless, enterprises of both countries fall into the category of the bottom quartile, although Croatian enterprises are nearer to the second quartile. Furthermore, in the block of leadership that reinforces learning, although they have similar scores, the Kosovan enterprises fall into the category of the bottom quartile, whereas Croatian enterprises fall into the second quartile. Generally, it is concluded that the enterprises of both compared countries failed to implement the LO. Although, Croatian enterprises scores are nearer than Kosovan enterprises to median benchmarking.

This research is conducted only in three sectors in Kosovan enterprises and the total sample size was $n=150$. Thus, we suggest a larger sample size for future researches. Another limitation of this study is that $50 \%$ of surveyed enterprises are small enterprises. Since a majority of authors emphasize that orientation towards LOs has been a concern, mainly for large enterprises. The clarification of Kerste et al. (2002) is that for SMEs, acquiring knowledge is interesting only if this knowledge can be acquired and distributed easily and will result in an immediate pragmatic increase of efficiency, higher margin of profit or competitive advantage. Similar opinion shared authors McAdam and Reid (2001), who agreed that SMEs are still reluctant in accepting the principles of knowledge management in their strategic thinking and daily routine. So, we suggest the future researches to include more large enterprises.

Based on the results of this empirical study, in the following, we have presented these recommendations for Kosovan enterprises:

- Creating an incentive learning environment for employees, known as the transformation of the organizational culture resistant to learning;

- Adapting new approaches to organizational learning culture and rapid adaptation to changes in the environment;

- Creating the thinking structure system; 
- Investing in talents making them professional masters;

- Leaders to be role models in gaining and transferring knowledge in the way to reinforce learning.

\section{REFERENCES:}

Adamska, M., \& Minárová, M. (2014). Role of learning organization in building consumer confidence. E+ M Ekonomie a Management, 17(1), 62-72.

Appelbaum, S. H. and Goransson, L. (1997), Transformational and adaptive learning within the learning organization: a framework for research and application. The Learning Organization, 4(3), 115-128.

Argyris, C., \& Schon, D. (1978). Organizational learning: A theory of action approach. Reading, MA: Addision Wesley.

Berisha Qehaja, A., \& Kutllovci, E. (2015). The Role of Human Resources in Gaining Competitive Advantage. Journal of Human Resource Management, 18(2), 47-61.

Birdthistle, N. (2008). Family SMEs in Ireland as learning organizations. The Learning Organization, 15(5), 421-436.

BSC Kosovo (2011). Entrepreneurship and Small Business Development in Kosovo, Pristina.

BSC Kosovo (2013). Entrepreneurship and Small Business Development in Kosovo in 2012, Pristina.

Bui, H., \& Baruch, Y. (2010). Creating learning organizations: a systems perspective. The Learning Organization, 17(3), 208-227.

Bullinger, H. J., Wörner, K., \& Prieto, J. (1997). Wissensmanagement heute: Daten, Fakten, Trends. Fraunhofer-Inst. für Arbeitswirtschaft und Organisation (IAO).

Djonlagic, S., Delic, A., \& Kovacevic, A. (2013). Developing Learning Organizations for Achievement of Competitive Advantages in Enterprises in Bosnia and Hercegovina. In Active Citizenship by Knowledge Management \& Innovation: Proceedings of the Management, Knowledge and Learning International Conference 2013 (pp. 781788). ToKnowPress.

Edmondson, A., \& Moingeon, B. (1998). From organizational learning to the learning organization. Management Learning, 29(1), 5-20.

Farrell, M. A. (2000). Developing a market-oriented learning organisation. Australian Journal of Management, 25(2), 201-222.

Finnigan, K. S., \& Daly, A. J. (2012). Mind the gap: Organizational learning and improvement in an underperforming urban system. American Journal of Education, 119(1), 41-71.

Fiol, C. M., \& Lyles, M. A. (1985). Organizational learning. Academy of Management Review, 10(4), 803-813.

Fischer, F., Bruhn, J., Gräsel, C., \& Mandl, H. (2002). Fostering collaborative knowledge construction with visualization tools. Learning and Instruction, 12(2), 213-232.

Garvin, D. Edmondson, A., and Gino, F. (2008). Is yours a learning organization? Harvard Business Review, 86(3),109-116. 
Gephart, M. A., Marsick, V. J., Van Buren, M. E., Spiro, M. S., \& Senge, P. (1996). Learning organizations come alive. Training \& Development, 50(12), 34-46.

Goh, S., \& Richards, G. (1997). Benchmarking the learning capability of organizations. European Management Journal, 15(5), 575-583.

Grieves, J. (2008). Why we should abandon the idea of the learning organization. The Learning Organization, 15(6), 463-473.

Hamel, G. (2006). The why, what, and how of management innovation. Harvard Business Review, 84(2), 72-84.

Horvat, Đ., \& Trojak, N. (2013). Learning organization in new economy. Interdisciplinary Management Research, 9, 183-195.

Jackson, S. E., DeNisi, A., \& Hitt, M. A. (Eds.). (2003). Managing knowledge for sustained competitive advantage: Designing strategies for effective human resource management (Vol. 21). John Wiley \& Sons.

Jamali, D., \& Sidani, Y. (2008). Learning organizations: diagnosis and measurement in a developing country context: The case of Lebanon. The Learning Organization, 15(1), 58-74.

Kerste, R., Muizer, A., \& Zoetermeer, A. (2002). Effective knowledge transfer to SMEs. Strategic Study B, 200202.

Kontoghiorghes, C., Awbre, S. M., \& Feurig, P. L. (2005). Examining the relationship between learning organization characteristics and change adaptation, innovation, and organizational performance. Human Resource Development Quarterly, 16(2), 185-212.

Krasniqi, B. A. (2007). Barriers to entrepreneurship and SME growth in transition: the case of Kosova. Journal of Developmental Entrepreneurship, 12(1), 71-94.

Learning Organization Survey, available at: https://hbs.qualtrics.com/jfe/form/SV_b7rYZGRxuMEyHRz, (accessed 20 November 2016).

Lee, H., \& Choi, B. (2003). Knowledge management enablers, processes, and organizational performance: An integrative view and empirical examination. Journal of Management Information Systems, 20(1), 179-228.

Ma, Z., \& Yu, K. H. (2010). Research paradigms of contemporary knowledge management studies: 1998-2007. Journal of Knowledge Management, 14(2), 175-189.

Marquardt, M. J. (2002). Building the learning organization: Mastering the 5 elements for corporate learning. Davies-Black Pub.

Marsick, V. J., \& Watkins, K. E. (2003). Demonstrating the value of an organization's learning culture: the dimensions of the learning organization questionnaire. Advances in Developing Human Resources, 5(2), 132-151.

McAdam, R., \& Reid, R. (2001). SME and large organisation perceptions of knowledge management: comparisons and contrasts. Journal of Knowledge Management, 5(3), 231-241.

Ministry of Trade and Industry (2011). SME Development Strategy for Kosovo 2012 - 2016 (with vision to 2020), Pristina.

Ministry of Trade and Industry (2015). 15 years of transition in Kosovo: Implications for trade, Pristina.

Mintzberg, H., Ahlstrand, B., \& Lampel, J. (1998). Strategic safari. A guided Tour through the Wilds of Strategic Management. 
Nonaka, I. \& Takeuchi, H. (1995). The Knowledge Creating Company: How Japanese Companies Create the Dynamics of Innovation. Oxford University Press, New York, NY.

O'Keeffe, T. (2002). Organisational learning: a new perspective. Journal of European Industrial Training, 26(2/3/4), 130-141.

Peci, F., Kutllovci, E., Tmava, Q. \& Shala, V. (2012). Small and medium enterprises facing institutional barriers in Kosovo. International Journal of Marketing Studies, 4(1), 95-107.

Pedler, M., Burgoyne, J. and Boydell, T. (1997), The Learning Company: A Strategy for Sustainable Development, McGraw-Hill, London.

Perlitz, M. (1997). Internationales Management. Stuttgart: Fischer.

Peters, T. (1987). Thriving on chaos. New York: Knopf.

Porter, M. R. (2016). The Correlation of Leader Traits and Learning Organizational Culture (Doctoral dissertation). Walden University.

Rebelo, T. M., \& Duarte Gomes, A. (2008). Organizational learning and the learning organization: reviewing evolution for prospecting the future. The Learning Organization, 15(4), 294-308.

Renner, F., Clark, C., Shilkin, B., Benn, J., Albatis, M., \& Howard, R. (2014). 'Thanks for being awesome': using the learning organisation model to enhance university library and IT client service. The Australian Library Journal, 63(2), 118-128.

Rowley, J., \& Gibbs, P. (2008). From learning organization to practically wise organization. The Learning Organization, 15(5), 356-372.

Salaman, G. and Butler, J. (1994), Why Managers Won't Learn. Managing Learning, 35-45.

Santa, M. (2015). Learning organisation review-a "good" theory perspective. The Learning Organization, 22(5), 242-270.

Senge M, Peter. (1990). The Fifth Discipline: The Art and Practice of Learining Organisation. Bantam Doubleday Dell Publishing Group, Inc.

Senge, P.M. (2006), The Fifth Discipline: The Art and Practice of the Learning Organization. Boadway Business.

Smith, P. A., \& Saint-Onge, H. (1996). The evolutionary organization: avoiding a Titanic fate. The Learning Organization, 3(4), 4-21.

Shipton, H., Zhou, Q., \& Mooi, E. (2013). Is there a global model of learning organizations? An empirical, cross-nation study. The International Journal of Human Resource Management, 24(12), 2278-2298.

The Boston Consulting Group (2010). Creating People Advantage 2010: How Companies Can Adapt Their HR Practices for Volatile Times. The Boston Consulting Group, Boston, MA.

Wang, S., \& Noe, R. A. (2010). Knowledge sharing: A review and directions for future research. Human Resource Management Review, 20(2), 115-131.

Watkins, K. E., \& Marsick, V. J. (1992). Building the learning organisation: a new role for human resource developers. Studies in Continuing Education, 14(2), 115-129.

Watkins, K. E., \& Marsick, V. J. (1993). Sculpting the learning organization: Lessons in the art and science of systemic change. Jossey-Bass Inc., 350 Sansome Street, San Francisco, CA 94104-1310. 